\title{
A magyar biztonságpercepció elemzése 2.
}

A Stratégiai Védelmi Kutatóintézet kutatási programjának keretében kezdtük meg a magyar biztonságpercepció átfogó elemzését egy reprezentatív közvéleménykutatás, és 10 darab, a Honvédelmi Minisztériumban készitett, félig strukturált interjú eredményeire támaszkodva 2019 őszén. E kutatási programot folytatva, 2020 őszén azt vizsgáltam, hogyan alakul a biztonságpercepciója azoknak a szakembereknek, akik a Honvédelmi Minisztériumon kivül, a Külgazdasági és Külügyminisztérium munkatársaként vagy a háttérintézményekben dolgozó szakértőként kapcsolódnak a magyar biztonság- és védelempolitikai szférához. A kutatás során 23 darab félig strukturált interjút készítettem a Külgazdasági és Külügyminisztérium, a Külügyi és Külgazdasági Intézet, valamint a Stratégiai Védelmi Kutatóintézet munkatársaival. E cikk az elkészült interjúk eredményeit elemzi és hasonlítja össze a 2019-es interjúk eredményeivel annak érdekében, hogy minél árnyaltabb képet kaphassunk a magyar biztonság-és védelempolitikai szféra biztonságpercepciójáról.

Kulcsszavak: Magyarország, biztonságpercepció, fenyegetettségpercepció, külpolitika, védelempolitika

\section{Etl Alex: The Analysis of Hungarian Security Perception 2.}

The Institute for Strategic and Defence Studies began to analyse the perception of security in Hungary, based on the results of a representative social survey and ten semi-structured interviews that were conducted at the Ministry of Defence during the autumn of 2019. As a follow-up to this initial research project, I also started to analyse the perception of those security and defence policy professionals who work either at the Ministry of Foreign Affairs and Trade or at various background institutions. During this process, I conducted 23 semi-structured interviews at the Ministry of Foreign Affairs and Trade, the Institute for Foreign Affairs and the Institute for Strategic and Defence Studies during the autumn of 2020. This study aims to analyse these interviews by comparing their results with the interviews from 2019, in order to provide a more comprehensive picture concerning the perception of security and perception of threats within the Hungarian security and defence policy community.

Keywords: Hungary, perception of security, perception of threats, foreign policy, defence policy

1 Etl Alex, a Nemzeti Közszolgálati Egyetem, Hadtudományi Doktori Iskola doktorandusza, SVKI tudományos segédmunkatársa, e-mail: etl.alex@uni-nke.hu 


\section{Bevezetés és módszertani keretek}

1999-től kezdődően a Stratégiai Védelmi Kutatóintézet több különböző tanulmányban vizsgálta a magyar biztonságpercepció alakulását. ${ }^{2}$ Lényegében e kutatási programot folytattuk 2019 öszén, amikor is egy 1000 fös közvélemény-kutatás eredményeire támaszkodva vizsgáltuk a magyar társadalom biztonságpercepcióját. ${ }^{3}$ Ezzel párhuzamosan pedig 10 félig strukturált interjút folytattam le a Honvédelmi Minisztériumban annak érdekében, hogy felmérjem hogyan alakul az ország biztonság- és védelempolitikájával napi szinten foglalkozó szakemberek biztonságpercepciója. Ahogy már akkor megjegyeztem, 10 félig strukturált interjú nem tekinthető reprezentatívnak a magyar biztonság- és védelempolitikai szféra egészére nézve, ugyanakkor úgy véltem, hogy az interjúk elkészítése és kielemzése fontos támpontként szolgálhat az alapvetően zárt, magyar biztonság- és védelempolitikai közösség belső dinamikáinak és percepcióinak feltérképezése során.

Annak érdekében, hogy e közösség percepciójáról még árnyaltabb képet kaphassunk, 2020 szeptemberében e kutatási pillért folytatva további 23 félig strukturált interjút készítettem a Külgazdasági és Külügyminisztérium, a Külügyi és Külgazdasági Intézet, valamint a Stratégiai Védelmi Kutatóintézet munkatársaival. A 23 interjúból tíz zajlott a Külgazdasági és Külügyminisztériumban. E tíz interjúalany mindegyike a helyettes-államtitkári szint alatt dolgozott, a Biztonságpolitikai és Non-Proliferációs Főosztályon, az EU Közös Külés Biztonságpolitikai és Szomszédságpolitikai Főosztályon, valamint a Nyugat-Balkán Főosztályon. Hét interjú zajlott a Külügyi és Külgazdasági Intézetben és hat interjú a Stratégiai Védelmi Kutatóintézetben. A potenciális interjúalanyok az interjúk elött megismerhették a főbb kérdéseket. E kérdések azt vizsgálták, hogy hogyan vélekedik az adott interjúalany a biztonság és a fenyegetés koncepciójáról, hogyan tekint Magyarország biztonság- és védelempolitikai helyzetére, hogyan vélekedik az ország szövetségeseiről és szövetségesi státuszáról, hogyan értékeli a különbözó állami és nem állami jellegü fenyegetéseket Magyarország szempontjából, mi a véleménye az európai védelmi együttmüködések jövőjéről, hogyan értékeli a Visegrádi Négyek biztonságpolitikai együttmüködését, és hogyan tekint a Magyar Honvédség fejlesztésére, valamint a védelmi kiadások alakulására.

E munkám során, az ily módon elkészített félig strukturált interjúk eredményeinek öszszehasonlítása alapján vizsgálom a magyar biztonságpercepció alakulását. Ahol releváns, ott a kapott adatokat összehasonlítom a 2019-ben a Honvédelmi Minisztériumban készült interjúk eredményeivel vagy a 2020-as Nemzeti Biztonsági Stratégia egyes pontjaival. Ezt módszertani szempontból az is lehetővé teszi, hogy a kérdések azonosak voltak a két felmérés során, így a válaszok is összehasonlíthatók lesznek. Fontos megjegyezni ugyanakkor, hogy a 2020. szeptemberi interjúk a koronavírus-járvány közben és közvetlenül a Fehérorosz válság, valamint a görög-török válság után készültek, így ezek a témák is markánsabban megjelenhetnek bennük. Értelemszerüen e pontok nem jelentek meg a 2019-es felmérésben, így az adatok összehasonlítása során e különbséget ennek fényében érdemes értelmezni.

Lásd bővebben: Radványi Lajos: A magyar lakosság biztonságfelfogása és értékpreferenciái, 1999-2008. Nemzet és Biztonság, 2. (2009), 2. 9-22.

3 Etl Alex: A magyar biztonságpercepció elemzése. Nemzet és Biztonság, 13. (2020), 2. 80-93.; Etl Alex - Tálas Péter: A magyar biztonságpercepció átalakulása 1999-2019 között. Nemzet és Biztonság, 13. (2020), 2. 94-112. 
A 2019-es interjúkkal együtt így már összesen 33 interjú áll rendelkezésre annak érdekében, hogy elemezhessük a magyar biztonságpolitikai közösség percepcióját. Ez a 33 interjú már szilárd alapot adhat a Honvédelmi Minisztériumban és a Külgazdasági és Külügyminisztériumban, valamint az e minisztériumokhoz kapcsolódó kutatóintézetekben a biztonságpolitikával foglalkozó szakemberek percepciójának vizsgálatához, ugyanakkor fontos megjegyezni, hogy nem állíthatjuk, hogy ezzel a teljes hazai biztonságpolitikai szférát reprezentálnánk. Az ugyanis ennél jóval kiterjedtebb, hiszen más kutatóintézetek, egyetemi tanszékek is kapcsolódnak hozzá. Bízom abban, hogy a jövőben a magyar biztonságpercepcióra vonatkozó kutatások még átfogóbbak lehetnek, és ennek mentén kerülhet majd sor e szélesebb közösség percepciójának vizsgálatára.

\section{A biztonság és a fenyegetés koncepciója}

Az interjúalanyokat először arra kértem, hogy mondják el, mi jut eszükbe a biztonság szóról. Az interjúalanyok több mint fele a biztonságot nem önmagában, hanem a fenyegetések hiányaként értelmezte - és ezzel párhuzamosan többen utaltak arra is, hogy ez a fajta megközelítés elsősorban korábbi tanulmányaikból, tankönyvszerű definíciókból fakad. Érdekes megfigyelni ezen a ponton azt is, hogy míg a korábban ismertetett társadalmi kutatás során a válaszadók túlnyomó többsége közvetlen élményeire asszociált a biztonság szó hallatán, addig a szakértői szint asszociációi sokkal közelebb állnak a biztonság tudományos jellegü koncepcionalizálásához. A definíció másik oldalaként volt interjúalany, aki hozzátette, hogy a fenyegetések hiányán túl, a biztonság definiáltható még a fenyegetések elhárításának képességével is. Volt olyan interjúalany, aki a biztonságot ezzel párhuzamosan egyfajta növekedésként, szabad, kényszer nélküli állapotként vagy természetes létállapotként definiálta. Több válaszadó kiemelte azt is, hogy a biztonságnak különböző szintjei (állami és nem állami), illetve különböző szektorai lehetnek, ami túlmutat a szűk katonai-politikai értelmezésen. Így például többen rámutattak a biztonság gazdasági, társadalmi, technológiai környezeti aspektusaira is, míg egy interjúalany konkrétan a NATO-ra és az Európai Unióra (EU, Unió) asszociált a válaszában. Ez a holisztikus személet alapvetően nagyban hasonlít a 2019-ben a Honvédelmi Minisztériumban elvégzett interjúk eredményeihez, amelyek során szintén több válaszadó a biztonság széles spektrumát és multiszektoriális jellegét emelte ki az asszociáció során. ${ }^{4}$

Amikor az interjúalanyokat arról kérdeztem, hogy mi jut eszükbe a fenyegetés szóról, a válaszok szintén meglehetősen széles skálán váltakoztak. A válaszadók közel fele arra mutatott rá, hogy a fenyegetések széles spektrumon változhatnak, több szektort érinthetnek. Ezzel párhuzamosan kiemelték, hogy a fenyegetések nemcsak katonai jellegüek lehetnek, hanem például gazdasági, társadalmi, technológiai vagy akár környezeti aspektusuk is lehet, illetve volt, aki az aktuális koronavírus-járvány kapcsán a fenyegetések közegészségügyi vonatkozását emelte ki. Több interjúalany hangsúlyozta, hogy a fenyegetéseknek gyorsan, dinamikusan változó jellegük lehet, míg más interjúalanyok a fenyegetések szint-

Etl (2020) i. m. 88. 
jeit különítették el a válaszukban, elválasztva egymástól az egyéni szintű, a hétköznapok menetét érintő fenyegetéseket és az állami szintü fenyegetéseket.

Az ezekhez hasonló, inkább elméleti szintű kategorizálások mellett néhány interjúalany konkrétabb asszociációkat is megnevezett a válaszában. Így például ketten Oroszországra, Kínára, illetve Oroszországra, Kínára és Iránra asszociáltak a fenyegetés szó hallatán. Emellett volt, aki a mediánjövedelem csökkenésére és a középréteg lecsúszására, volt, aki a politikai élet polarizálódására, és volt, aki a társadalom/gazdaság digitális technológiai kitettségére, illetve a kiberfenyegetésekre asszociált a válaszában. Három válaszadó ezzel szemben a fenyegetések szubjektív megitélését hangsúlyozta, kiemelve, hogy a fenyegetések nem mindig egyértelmüen valósak, még akkor sem, ha az egyén fenyegetésként értelmezi azokat. Sőt, egy interjúalany arra is rámutatott, hogy bizonyos fenyegetések (például a terrorizmus) kifejezetten a lakosság percepcióját próbálják megváltoztatni, amire az államnak reagálnia is kell annak érdekében, hogy az állam müködésébe vetett bizalom és a lakosság biztonságérzete ne rendüljön meg.

\section{Az ország biztonság- és védelempolitikai helyzetének percepciója}

Bizonyos mértékü konszenzus mutatkozik abban, hogy a válaszadók hogyan látják Magyarország biztonság- és védelempolitikai helyzetét. Nem volt ugyanis olyan interjúalany, aki általában véve negatívan értékelte volna az ország helyzetét, sőt, volt olyan interjúalany is, aki úgy fogalmazott, hogy „Magyarország védelempolitikai helyzete még sosem volt ilyen jó". Az interjúalanyok alapvetően jónak, stabilnak és biztonságosnak látták az ország helyzetét és a többség ezt mindenekelőtt Magyarország nyugati/transzatlanti szövetségesi tagságával állította párhuzamba, ami a válaszadók szerint nagyban hozzájárult e stabilitás kialakulásához. Többen kiemelték azt az aspektust is, hogy Magyarország területi integritására nézve jelenleg nem azonosítható fenyegetés.

A nemzetközi környezet változásával kapcsolatban ugyanakkor sokkal negatívabb percepció tükröződött. Az interjúalanyok válaszaikban jellemzően arra is felhívták a figyelmet, hogy a biztonsági környezet inkább romló tendenciát mutat, elsősorban a globális biztonsági környezet romlása miatt. Ennek mentén többen kiemelték, hogy az ezen a szinten tapasztalható kihívások, alapvetően nem hagyományosak, hanem sokkal inkább a biztonságpolitika nem katonai területeihez kapcsolódnak (például koronavírus-járvány és annak gazdasági hatásai, illegális migráció, társadalmi kihívások, elszegényedés, kiberbiztonság, globális hatalmi eltolódás, társadalmak dezintegrációja).

Hét interjúalany rámutatott arra is, hogy a globális jellegü problémák mellett, Magyarország közvetlen biztonsági környezete is inkább romló tendenciát mutatott az elmúlt években, elsősorban a szomszédos Ukrajnában zajló, aktív katonai konfliktus miatt. Ukrajna mellett pedig többen rámutattak a Nyugat-Balkán instabilitásának veszélyére is, ami közvetett, nem katonai módon befolyásolhatja Magyarország biztonságát is. Egy interjúalany ugyanakkor ezzel épp ellentétes véleményt fogalmazott meg, és azt hangsúlyozta, hogy az orosz ambíciók elértek egy határt az elmúlt években és a Nyugat-Balkán inkább stabilizálódik, míg egy másik interjúalany arra hívta fel a figyelmet, hogy a minket érintő kihívásoknak (például a Nyugat-Balkánon) nagyobb hatása, de kisebb esélye van. 
Összehasonlítva e válaszokat a 2019 során a Honvédelmi Minisztériumban készült interjúkkal azt mondhatjuk, hogy alapvetően konszenzus van arról, hogy az ország biztonságpolitikai helyzete - mindenekelőtt a szövetségesi rendszerének köszönhetően - stabil és pozitív összeképet mutat. ${ }^{5}$ A 2020-ban készült interjúk többsége ugyanakkor markánsabban mutat rá arra, hogy e stabilitás mellett az ország biztonságpolitikai környezete inkább romló tendenciát mutat. Ez utóbbi észrevétel egyébként összhangban van a 2020-as Nemzeti Biztonsági Stratégia által felvázolt környezetértékeléssel is. ${ }^{6}$

\section{A szövetségesek megítélése}

Bizonyos konszenzus azonosítható a tekintetben is, hogy a válaszadók mely országokat tekintik Magyarország legfontosabb biztonságpolitikai partnereinek. Gyakorlatilag minden válaszadó alapvetően a NATO- és/vagy az EU-szövetségeseket sorolta a legfontosabb partnerek közé. Az ezen túl nevesített országok között egy-két kivétellel három szövetséges dominálja a percepciót a második körben készített interjúk alapján is (és ezek közül a legtöbbször mindhárom megjelent a válaszokban): az Amerikai Egyesült Államok (Egyesült Államok), Németország és a V4-ek (1. ábra). Fontos különbségtétel ugyanakkor e három között, hogy míg az Egyesült Államokat elsősorban a NATO-n belüli szerepe miatt említették az interjúalanyok, addig Németország Európán belüli gazdasági, politikai súlya miatt és a honvédelmi beszerzések mentén került többször elötérbe. A V4-ek kapcsán azonban nincs ilyen stabil konszenzus, hiszen több interjúalany inkább a csoport politikai, normatív jellegét hangsúlyozta, míg volt olyan interjúalany is, aki direkt azt hangsúlyozta, hogy a V4eket nem sorolná a legfontosabb szövetségesek közé a csoport biztonságpolitikai együttmüködésének korlátjai miatt, míg más arra mutatott rá, hogy a V4-ek közül inkább csak Lengyelország tekinthető ebből a szempontból jelentős partnernek. Az Egyesült Államok kapcsán pedig több interjúalany rámutatott arra is, hogy Washington jövőbeli külpolitikája egyfajta „kiszámíthatatlanságot” jelent Magyarország és Európa számára.

E szövetségesek mellett három válaszadó is kiemelte Franciaországot mint fontos szövetségest az európai védelempolitika jövője szempontjából. Három interjúalany említette az Egyesült Királyságot, kettő Olaszországot, valamint kettő a nem V4-tag szomszédos országokat, amelyek fontosak Magyarország biztonságpolitikája szempontjából.

Azzal a kérdéssel kapcsolatban, hogy „mely országokkal lenne célszerű Magyarországnak a jelenleginél szorosabb katonai együttmüködést kialakítani”, már jobban megoszlanak a vélemények. A válaszadók több mint fele ezen a ponton elsősorban a V4-eket említette, kiemelve, hogy az együttműködés biztonságpolitikai pillérét is érdemes lenne megerősíteni (a már egyébként létező politikai/normatív aspektus mellett). A többség tehát elsősorban közép-európai szinten gondolkozik e tekintetben. Ezt erősíti az is, hogy két interjúalany említette Romániát a válaszában, hangsúlyozva, hogy a biztonságpolitikai együttmüködés a két ország politikai kapcsolatainak javulását is elősegíthetné. Két interjúalany pedig külön kiemelte Csehországot, mint akivel az együttműködés fontos lehet a közép-európai védelmi együttműködések szempontjából. Ez utóbbiakat ugyanakkor árnyalja, hogy két másik

Etl (2020) i. m. 89.

1163/2020. (IV. 21.) Korm. határozat Magyarország Nemzeti Biztonsági Stratégiájáról. 
interjúalany épp a Csehországgal és a Romániával történő együttmüködés potenciális korlátait hangsúlyozta, a téma megítélése tehát kissé ellentmondásosnak tekinthető a szakértői szinten belül. A régión kívüli országokat tekintve négy interjúalany is Franciaországot emelte ki, mint aki fontos partner lehet az európai védelmi együttmüködések mentén. Két válasz utalt az Egyesült Királyságra, mint akivel a Brexit után érdemes lenne egy rendezett biztonságpolitikai kapcsolatot kialakítani, és három további válasz említette a szövetségen kívüli Izraelt olyan országként, aki biztonságpolitikai szempontból fontos partnere lehetne Magyarországnak. Egy válaszadó emelte ki Törökországot a védelmi ipari együttmüködés lehetősége miatt, ezt azonban árnyalja, hogy a későbbi kérdések kapcsán mások azt hangsúlyozták, hogy Ankara zsarolási potenciálja Európa szempontjából bizonyos fenyegetéseket jelent.

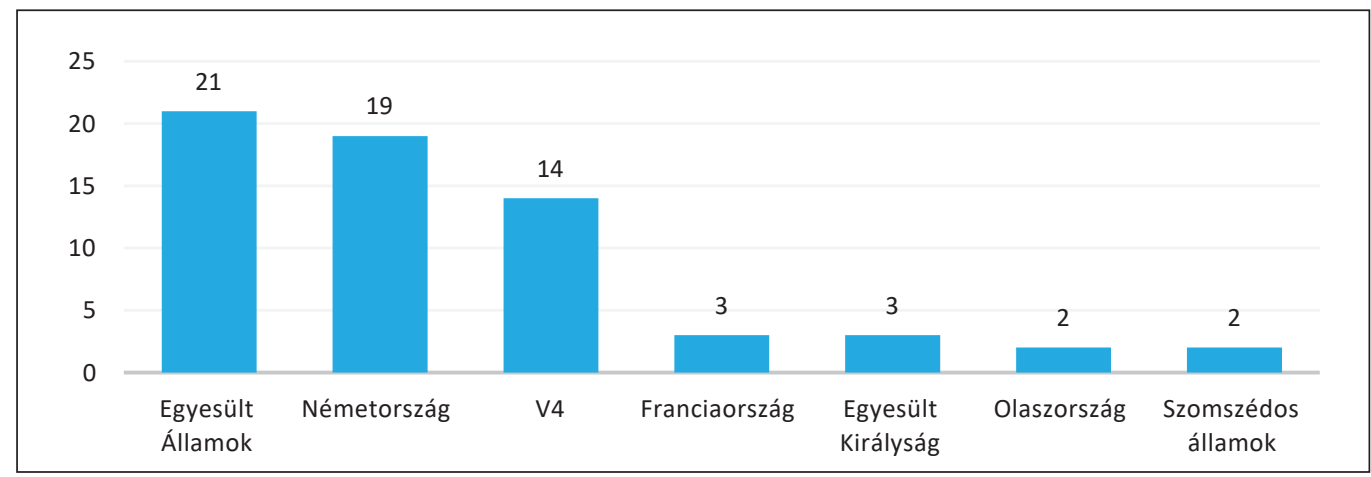

1. ábra: Magyarország legfontosabb biztonságpolitikai partnerei. A számok azt jelölik, ahány interjúalany az adott országot/országcsoportot említette a 2020-as interjúk során

Forrás: a szerző szerkesztése

A szövetségesek megítélését tekintve tehát összességében meglehetősen hasonló eredmények születtek a Honvédelmi Minisztériumban folytatott interjúkhoz viszonyítva, ahol szintén stabil konszenzus mutatkozott Németország, az Egyesült Államok és a V4-ek meghatározó szerepéről e tekintetben. ${ }^{7}$ Fontos megállapítás tehát, hogy a magyar biztonság- és védelempolitikai szféra - szinte kivétel nélkül - elsősorban e szövetségesek mentén alakítja percepcióját. A 2020. szeptemberi interjúkban ugyanakkor markánsabban megjelenik az igény a V4-ek biztonság- és védelempolitikai együttmüködések elmélyítésére és tartalommal való feltöltésére. Mindkét interjúkörben megjelent emellett Franciaország is olyan országként, amellyel Magyarországnak érdemes lenne fokoznia biztonságpolitikai együttmüködését a jövőben, köszönhetően Párizs meghatározó európai szerepének.

Az ország szövetségesi rendszerével kapcsolatos stabil konszenzus mutatkozott akkor is, amikor az interjúalanyokat arról kérdeztem, hogy véleményük szerint amennyiben valamely szövetséges NATO- vagy EU-tagállamot külső támadás érne, Magyarországnak/a Magyar Honvédségnek az adott állam megsegítésére kellene-e indulnia. A válaszadók egyetértettek abban, hogy Magyarországnak segítenie kellene a szövetségeseit egy ilyen

Etl (2020) i. m. 89. 
esetben, különösen azért, mert a szövetség belső kohéziója és fennmaradása, ezáltal pedig Magyarország biztonsága is jelentős mértékben ettől a rendszertől függ. Így például többen hangsúlyozták azt is, hogy fordított esetben Magyarország is csak e szövetségi garanciákra tudna támaszkodni, és jogosan várná a segítséget szövetségeseitől. E ponton tehát a válaszok nagyban hasonlítanak a Honvédelmi Minisztériumban lefolytatott interjúk eredményeihez, amelyek szintén jelentős elkötelezettséget mutattak a szövetségesek irányába. ${ }^{8}$

A 2020-as interjúk alatt ketten érveltek úgy, hogy az EU-tagállamok felé nem feltétlenül áll fenn ugyanez a kötelezettség, mint a NATO-tagállamok esetében, köszönhetően annak, hogy nem rendezett a jogi helyzete egy ilyen esetnek. Egy másik interjúalany úgy fogalmazott, hogy véleménye szerint az EU kölcsönös segítségnyújtási klauzulája szándékosan nem fogalmaz egyértelműen, és éppen ezért nem egyértelmü, hogy mi történne egy ilyen esetben az EU-tagállamot ért támadás után, míg egy másik válaszadó úgy érvelt, hogy a kölcsönös segítségnyújtási klauzula nem feltétlenül katonai képességek felajánlását jelenti, hanem az olyan jellegü segítségnyújtást, amelyre épp szükség van. Ezzel együtt ugyanakkor az is látható, hogy a 2020. őszi interjúalanyok nagyobb arányban látják e szövetségesi kötelezettséget az EU-tagállamokra kiterjesztve, mint a Honvédelmi Minisztériumban megkérdezett interjúalanyok, akik körében jóval ambivalensebb volt az uniós tagállamok irányába fennálló kötelezettségek megítélése. ${ }^{9}$ Ez ugyanakkor lehet annak is köszönhetö, hogy az elmúlt év során markánsabban jelent meg ez a kérdés az Unió politikai napirendjén.

Bár láthattuk, hogy az interjúalanyok egyetértettek abban, hogy a szövetségesekkel szolidaritást kell vállalni külső támadás esetén, több válaszadó is árnyalta a válaszát bizonyos szempontok mentén. Így például egy válaszadó amellett érvelt, hogy ha egy tagállam a saját érdekei mentén beleugrik egy indokolatlan konfliktusba például Oroszországgal, akkor mérlegelni kell, hogy megéri-e az egész szövetséget is mellé állítani. Rajta kívül két megkérdezett mutatott rá arra, hogy a „kibertámadások attribúciójának” nehézségei miatt nem feltétlenül egyértelmü, hogy adott esetben mi alapozna meg egy NATO 5. cikk szerinti müveletet, és az egyikük külön kiemelte, hogy nem tartja jónak, hogy ha például egy tagállamot kibertámadás ér, akkor egyből 5. cikk szerinti művelet legyen a válasz. Két további interjúalany pedig arra mutatott rá, hogy a segítségnyújtás mértéke mindig mérlegelés kérdése. Fontos ugyanakkor arra is rámutatni, hogy ezek az interjúalanyok is hangsúlyozták, hogy váratlan, katonai támadás esetén fennáll a szövetségesi kötelezettség, és Magyarországnak segítenie kell a megtámadott szövetségesét.

A szövetségesek megítélését tekintve az interjúalanyok percepciója összességében a 2020-as Nemzeti Biztonsági Stratégiában rögzítettekre reflektál kisebb hangsúlykülönbségekkel, hiszen a stratégia is hangsúlyozza Németország, a V4-ek és az Egyesült Államok kiemelt szerepét Magyarország biztonság- és védelempolitikája szempontjából. ${ }^{10} \mathrm{~A}$ stratégia által felállított - nem feltétlenül explicit priorizálási - sorrend esetében ugyanis az első helyen a V4-eket, a második helyen Németországot, a harmadik helyen pedig az Egyesült Államokat említi a partnerek között (tehát épp fordítva, mint az interjúalanyok esetében).

Etl (2020) i. m. 91.

Uo. 91.

10 1163/2020. (IV. 21.) Korm. határozat.; Csiki Varga Tamás - Tálas Péter: Magyarország új nemzeti biztonsági stratégiájáról. SVKI Elemzések, (2020), 17. 
Abban ugyanakkor konszenzus mutatkozik, hogy e három partner tekinthető a legfontosabbnak Magyarország biztonság- és védelempolitikája szempontjából. Látványos különbség mutatkozik ugyanakkor Törökország megítélésével kapcsolatban, amely a stratégia alapján kiemelt fontosságú partnernek tekinthető, az interjúalanyok percepciójában ugyanakkor ez nem tükröződik. ${ }^{11}$ A partnerségek keretét adó szövetségi rendszert illetően azonban strabil konszenzus azonosítható, hiszen a stratégia is úgy fogalmaz, hogy „Magyarország biztonság- és védelempolitikájának elsődleges nemzetközi keretét a NATO és EU tagsága jelenti”. ${ }^{12}$

\section{Fenyegetések}

Amikor a válaszadókat arról kérdeztem, hogy véleményük szerint mely tényező van leginkább negatív hatással Magyarország biztonságára, összesen nyolcan említették meg válaszuk során a koronavírus-járványt és annak gazdasági/társadalmi hatásait, ami jól érzékelteti azt is, hogy a járvány által okozott problémák jelentős mértékben beépültek a szakértői biztonságpercepcióba is (2. ábra). Ezen túlmenően öt interjúalany utalt arra, hogy a nagyhatalmak közti konfliktusok fokozódása negatívan hat Magyarország biztonságára, és ez összességében szükíti Magyarország mozgásterét is a nemzetközi kapcsolatokban. Egy interjúalany pedig úgy foglalta össze ezt a problémakört, hogy a nagyhatalmi rivalizálásból „nem tudunk kijönni nyertesen”.

A globális tendenciákat vizsgálva négy interjúalany rámutatott a globális demográfiai kihívásokra, amelyek hosszú távon különböző kihívásokat okozhatnak, illetve heten említették meg a globális klímaváltozást olyan tendenciaként, amely negatívan érintheti Magyarország biztonságát.

Két interjúalany utalt arra, hogy az EU-n és NATO-n belüli kohézió csökkenése és a feszültségek fokozódása negatívan hat Magyarország biztonságára. Három interjúalany pedig belső jellegü kihívásokat nevezett meg olyan tényezőként, amelyek a leginkább negatívan hatnak Magyarország helyzetére: így például egy interjúalany a „korrupt, előre nem gondolkozó" politikai elitet; egy a társadalmi kohézió csökkenését és a szélsőjobboldali csoportok térnyerését; egy pedig a „kulturális széttagoltságot” és az elit szintű konszenzusok hiányát említette meg a válaszában.

A nem állami jellegű fenyegetéseket értékelve az interjúalanyok közel fele utalt valamilyen formában a terrorizmusra mint fenyegetésre, ugyanakkor a legtöbben közülük azt is hangsúlyozták, hogy Magyarország nem tekinthető első számú célpontnak e tekintetben. Mások arra mutattak rá, hogy bár nem volt precedens a nyugatihoz hasonló terrortámadásokra, ugyanakkor ennek lehetőségét nem lehet teljes mértékben kizárni. Két interjúalany Magyarország tranzit szerepét emelte ki a terrorizmus kapcsán, míg két másik interjúalany amellett érvelt, hogy Magyarországon az iszlamista terrorizmus azért kevésbé fenyegetö, mert a muszlim közösségek ,jól integráltak”. Egy válaszadó emelte ki a romagyilkosságok precedensét a terrorizmus kérdése kapcsán.

11 1163/2020. (IV. 21.) Korm. határozat. 109-115. pont. 2111.

12 1163/2020. (IV. 21.) Korm. határozat, 91. pont. 2109. 


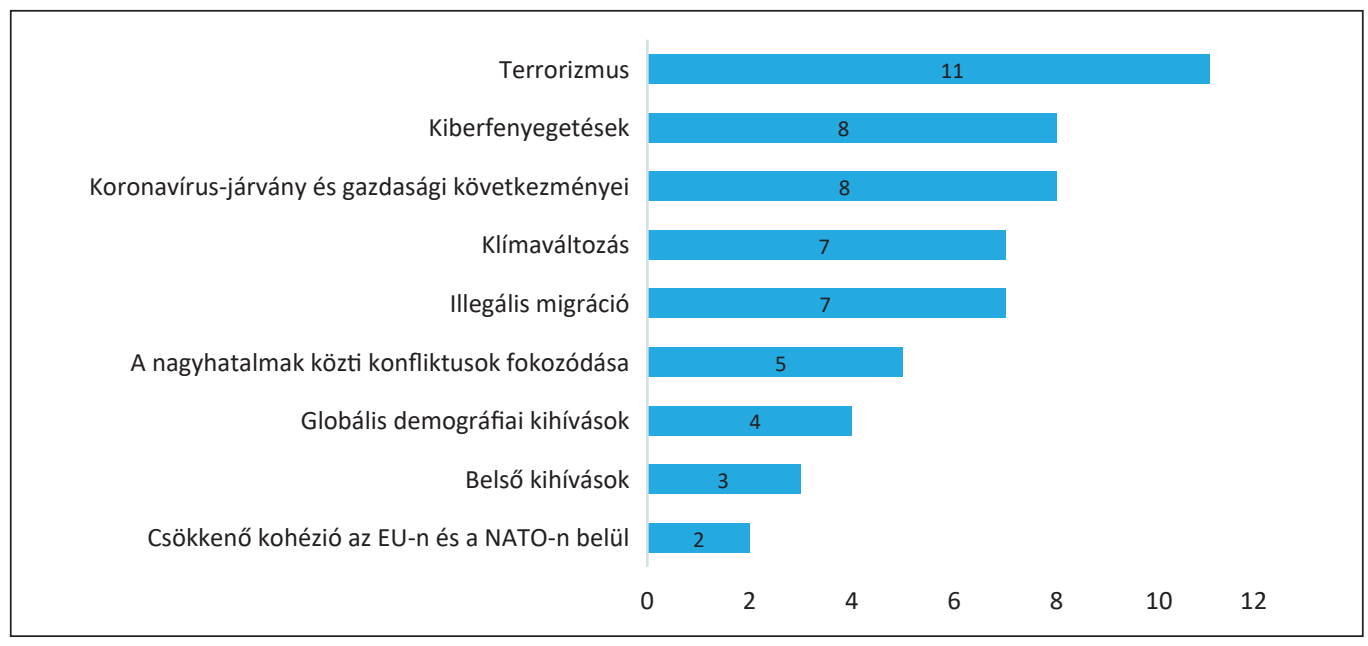

\section{2. ábra: A 2020-as interjúk során azonosított nem katonai fenyegetések (A számok azt jelölik, ahány interjúalany az adott fenyegetést említette)}

Forrás: a szerző szerkesztése

A terrorizmuson túl, hét interjúalany emelte ki az illegális migráció kérdését olyan ügyként, amely fenyegetést jelenthet Magyarország számára. Ezzel kapcsolatban többen rámutattak arra is, hogy a klímaváltozás kérdése és fokozódása felerősítheti a migrációs trendeket is hosszú távon. Öt interjúalany ugyanakkor ezzel szemben épp azt hangsúlyozta a válaszában, hogy a migrációt nem sorolná a nem állami fenyegetések közé (míg egy interjúalany inkább következményként és nem fenyegetésként értékelte a témát). Ez az ambivalencia pedig alapvetően a migráció jelentette fenyegetés mértékével kapcsolatos ellentmondásra mutat rá a szakértői szinten belül.

Nyolc interjúalany emelte ki válaszában a kibertér fontosságát és a kibertámadások jelentette fenyegetést Magyarország szempontjából. Ennek kapcsán többen rámutattak arra is, hogy e fenyegetések összekapcsolódhatnak a szervezett bünözés kérdésével, míg két interjúalany azt emelte ki, hogy a kiberbünözők lehetnek nem állami szereplők, de dolgozhatnak állami megbízásra is. Egy másik interjúalany arra mutatott rá, hogy egy nagyobb kibertámadás „megkérdőjelezheti az államba vetett hitet,” míg egy válaszadó azt hangsúlyozta, hogy a kibertérben „alacsony a belépési küszöb egy korlátozott támadáshoz”, Magyarország kitettsége pedig fokozódik. Ehhez kapcsolódva egy interjúalany a technológiai multinacionális vállalatok befolyásának növekedését emelte ki a válaszában a potenciális fenyegetések közt.

A válaszadók egyetértettek abban a kérdésben, hogy jelenleg nincs olyan állam, amely direkt módon katonai fenyegetést jelentene Magyarország számára. Ezzel együtt ugyanakkor 15 válaszadó azonosított különböző országokat, amelyek más, nem katonai típusú fenyegetést jelenthetnek az ország biztonsága szempontjából (3. ábra). 


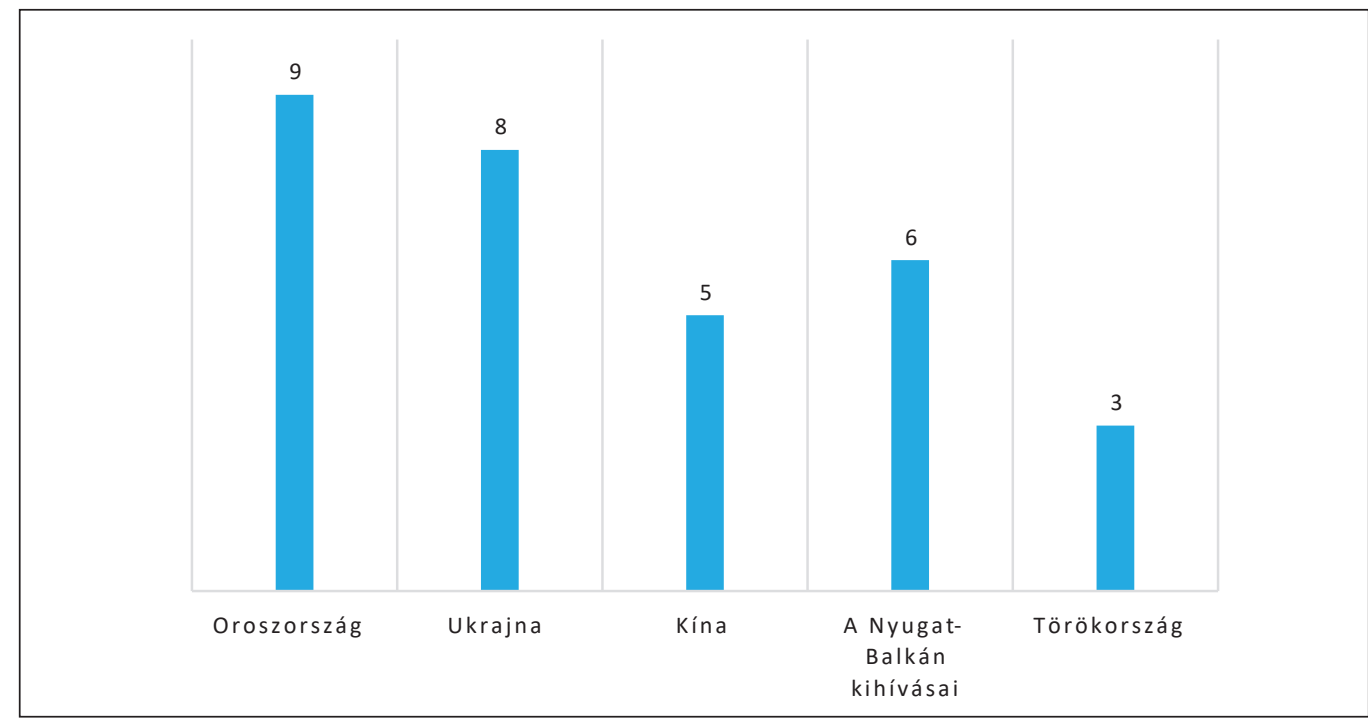

3. ábra: Országok, amelyek nem katonai jellegü kihívást jelenthetnek Magyarország számára (A számok azt jelölik, ahány interjúalany az adott országot/országcsoportot említette a 2020-as interjúk során)

Forrás: a szerző szerkesztése

Így például összesen kilenc interjúalany utalt a válaszaiban arra, hogy Oroszország egyfajta kihívást vagy fenyegetést jelenthet Magyarország számára, ennek sajátosságairól ugyanakkor megoszlanak a vélemények. Többen közülük a hibrid és nemzetbiztonsági jellegü vagy dezinformációs kihívásokat emelték ki Oroszország kapcsán, míg mások inkább az Oroszország jelentette fenyegetés szövetségre (például Baltikumra) gyakorolt hatását hangsúlyozták, amelyek bizonyos kihívások elé állíthatják hazánkat, egy válaszadó pedig Magyarország energetikai függőségére utalt orosz viszonylatban. Ahogy azonban arra már utaltam, egy válaszadó ezzel szemben úgy vélekedett, hogy az orosz ambíciók „elértek egy határt", míg egy másik amellett érvelt, hogy Oroszország racionális, kezelhetö állam, nem jelent fenyegetést, csak mérsékelt kihívást.

Nyolc interjúalany említette Ukrajnát olyan államként, amely egyfajta kihívást jelenthet Magyarország számára. A legtöbb interjúalany ezzel kapcsolatban az ukrajnai magyarok helyzetét emelte ki, amely egyfajta fenyegetést jelenthet, míg mások általában véve Ukrajna belső instabilitását és az ukrán társadalom bizonyos elemeinek radikalizálódását emelték ki válaszukban. Két interjúalany ugyanakkor Románia kapcsán is arra mutatott rá, hogy az ott élő magyar kisebbség helyzete és kitettsége kihívásokat okozhat a két ország bilaterális viszonyában.

Összesen öt válaszadó utalt a Kína jelentette kihívásra, amelyet elsősorban nemzetbiztonsági vagy technológia szempontból találtak aggályosnak, míg egy válaszadó „civilizációs” kihívásként értékelte azt. Egy interjúalany ugyanakkor arra mutatott rá, hogy a kínai politikai rendszer nem értelmezhető kelet-közép-európai kontextusban (szemben például az orosz politikai rendszerrel) és ennélfogva Kína nem jelent olyan szintű kihívást 
a régióban, valamint a kínai befolyás is korlátozott marad, míg egy másik válaszadó arra mutatott rá, hogy Magyarországnak sosem volt vitás kérdése Kínával.

Bár jellemzően az interjúalanyok nem említettek konkrét országot, ugyanakkor hatan utaltak a válaszaikban arra, hogy a balkáni konfliktusok kiújulása, illetve a balkáni országok politikai instabilitása több szempontból is kihívások elé állíthatják Magyarországot (ugyanakkor ezek leginkább közvetett hatásokban és nem direkt, Magyarországgal szembeni fenyegetésként jelentkeznének).

Három interjúalany utalt a válaszai során arra, hogy Törökország a migráció kérdése kapcsán rendelkezik olyan „zsarolási potenciállal," amely jelentős kihívás az Európai Unió számára. Emellett ketten azt is kiemelték, hogy a török-görög konfliktus veszélyt jelent a NATO belső kohéziójára is, ami bizonyos kérdéseket felvet a szövetség kollektív védelmi funkcióival kapcsolatban is.

Összehasonlítva e válaszokat a Honvédelmi Minisztériumban készített interjúk eredményeivel megállapíthatjuk, hogy a nem állami fenyegetések megítélése meglehetősen hasonló a szakértők körében, és elsősorban a terrorizmust, a kibertámadásokat és a migrációt emelik ki e kérdés kapcsán - igaz ugyan, hogy ez utóbbival kapcsolatban a 2020. őszi interjúk nagyobb ambivalenciát mutatnak. ${ }^{13} \mathrm{Az}$ is látható, hogy konszenzus van a tekintetben, hogy Magyarországot nem fenyegeti egy állam sem katonailag, azonban többen kiemelték Oroszországot, Ukrajnát, Kínát és Törökországot olyan államként, amelyek bizonyos jellegű fenyegetést vagy kihívást jelenthetnek Magyarország számára különböző szektorokban. Ezen túl pedig az is látható, hogy a koronavírus-járvány 2020 őszére markánsan beépült a szakértői biztonságpercepcióba. A 2020. őszi interjúk során erőteljesebben jelent meg a globális hatalmi versengés olyan témaként, amely negatívan befolyásolhatja Magyarország biztonságát. Ehhez hasonlóan az interjúalanyok által megjelölt kihívások jellemzően megjelennek a 2020-as Nemzeti Biztonsági Stratégiában is, igaz ugyanakkor, hogy kisebb hangsúlyeltolódások e ponton is azonosíthatók (például a globális felmelegedés kérdése némiképp markánsabban jelenik meg a percepcióban, mint a dokumentumban). Oroszországgal és Kínával kapcsolatban a stratégia óvatosan fogalmaz, és egyszerre tekint lehetőségként és kihívásként a két országra.

Előbbi kapcsán kiemeli a szövetség (NATO) és Moszkva közti feszültségekből fakadó problémákat, és hangsúlyozza, hogy miközben Magyarország „prioritásnak tartja a NATO és az EU kohéziójának megőrzését - érdekelt a magyar-orosz kapcsolatok és gazdasági együttmüködés pragmatikus fejlesztésében", míg utóbbi kapcsán a stratégia szerint „gazdasági együttmüködés lehetőségeinek kiaknázása során tekintettel kell lenni azokra a kitettségből adódó tényezőkre is, amelyek a feltörekvő Kína a kritikus infrastruktúrába történő beruházásai, a legfejlettebb infokommunikációs technológia esetleges szállítójaként való megjelenése és általában a regionális befolyásának megerősödése révén keletkeznek". ${ }^{14}$ Ukrajna némiképp markánsabban jelenik meg az interjúalanyok percepciójában, mint a biztonsági stratégiában, azonban a dokumentum szintén hangsúlyozza, hogy Magyarország érdekelt egy stabil és erős Ukrajna létrejöttében, ugyanakkor „az ukrán nemzettudat erösítését szolgáló legitim törekvések nem járhatnak a kárpátaljai magyar

13 Etl (2020) i. m. 89-90.

14 1163/2020. (IV. 21.) Korm. határozat, 118., 119. pont. 2111-2112. 
közösség szerzett jogainak csorbulásával”. ${ }^{15}$ Törökország pedig - mint ahogy korábban említettük - kiemelt fontosságú partnerként jelenik meg a stratégiában, e tekintetben tehát ellentétes percepciót azonosíthatunk az interjúk és a dokumentum elemzése alapján. ${ }^{16}$

A 2020-as interjúk alapján összességében megállapítható, hogy a megkérdezettek biztonságpercepciójában számos, különböző jellegű kihívás és fenyegetés jelenik meg. Nem azonosítható ugyanakkor olyan fenyegetés, amely kizárólagosan dominálná a válaszadók biztonságpercepcióját, bár több olyan téma is van, amelyet a válaszadók közel fele érintett (például Oroszország, Ukrajna, migráció, terrorizmus, koronavírus), ennélfogva pedig markánsan megjelennek a szakemberek percepciójában. Fontos ugyanakkor azt is látni, hogy hat interjúalany egyáltalán nem azonosított konkrét nem állami fenyegetéseket Magyarországra nézve, míg nyolcan azt hangsúlyozták, hogy nincs állam, ami bármilyen módon fenyegetést jelentene Magyarország számára. Ez utóbbi pedig megint csak azt jelzi, hogy a szakértők jelentős része szerint Magyarország biztonságpolitikai helyzete alapvetően stabil és pozitív.

\section{Az európai védelmi együttmúködések jövője}

Fontos hasonlóság azonosítható a megkérdezettek között az európai védelmi együttmüködés terén, hiszen a válaszadók mindegyike úgy vélekedett, hogy alapvetően szükség van a közös európai katonai képességek megerősítésére. Ezen túlmenően viszont a megvalósítás módjával kapcsolatban már jelentősen megoszlanak a vélemények. A válaszadók közti leginkább szembeötlő különbség, hogy a Külgazdasági és Külügyminisztériumban dolgozó interjúalanyok - egy-két kivételtől eltekintve - végig hangsúlyozták, hogy az európai képességek megerösítése nem történhet a transzatlanti, NATO-struktúrák rovására. Tehát e válaszadók alapvetően amellett érveltek, hogy az európai védelmi képességeknek a NATO európai pillérét kell erősíteniük, míg az „önjáró EU modell nem konstruktív”. A minisztériumon kívüli szakértői interjúk - szintén egy-két kivételtől eltekintve - azonban jóval kevésbé hangsúlyozták ezt az aspektust, és sokkal inkább az európai védelem hatékonyságára, Európa nagyobb szerepvállalására és Európa relatív hatalomvesztésére fókuszáltak a válaszaik során.

A gyakorlati szinten, azaz a konkrét európai képességek kapcsán is megoszlanak a vélemények. Több interjúalany kiemelte a szállítási, logisztikai, mobilitás és kommunikációs képességek megerősítésének fontosságát, amelyek az európai haderők önálló müködését segíthetik elő. Néhány válaszadó ezzel szemben sokkal kevésbé a kemény, katonai biztonsághoz kapcsolódó együttmüködést emelte ki, és inkább a katasztrófavédelem, polgári védelem kérdését hangsúlyozta. Két interjúalany utalt a kibervédelmi képességek megerösítésének fontosságára és a válaszadási képességek létrehozására. Mindösszesen egy válaszadó említette a nukleáris elrettentés kérdését, hangsúlyozva, hogy a francia nukleáris védőernyő európai kiterjesztése „érdemi integráció nélkül nem képzelhető el”. Ugyanez az interjúalany arra is rámutatott, hogy bizonyos modern képességek (például űrfegyverek, jövő

\footnotetext{
15 Ez feltehetőleg annak köszönhető, hogy 2020 során gyakrabban került a politikai közbeszéd fókuszába az ukrán-magyar viszony alakulása. 1163/2020. (IV. 21.) Korm. határozat, 88. pont. 2109.

16 1163/2020. (IV. 21.) Korm. határozat, 115. pont. 2111.
} 
harckocsija, jövő vadászrepülőgép-rendszere stb.) annyira drágák, hogy azok fejlesztése csak közösen képzelhető el. Ezzel szemben egy másik interjúalany azt hangsúlyozta, hogy véleménye szerint a „közös beszerzés vágyálom” az európai államok közti bizalmatlanság miatt. Arra ugyanakkor több interjúalany is rámutatott, hogy a konkrét képességek létrehozásán túl, az európai védelmi együttmüködés megerősítése elsősorban inkább politikai akarat kérdése, míg két további interjúalany azt hangsúlyozta, hogy a novemberi amerikai elnökválasztás kimenetele felgyorsíthatja az európai védelmi képességek megerősítését.

A válaszok alapján tehát összességében az látszik, hogy bár a magyar biztonság- és védelempolitikai szféra egyetért az európai védelmi képességek megerősítésének szükségességében, nincs ugyanakkor konszenzus ennek módját illetően. Látványos eltérések azonosíthatók az együttmüködés mélységére vonatkozó percepciók és a NATO szerepére vonatkozó percepciók terén is.

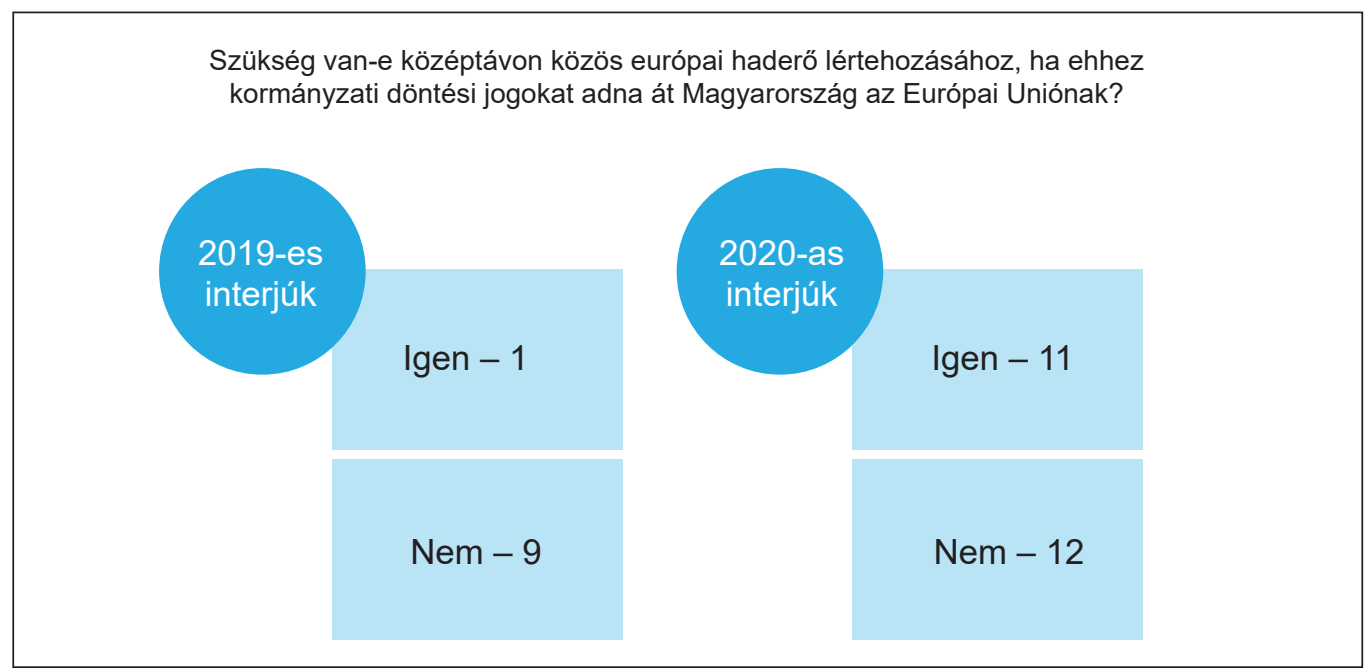

\section{4. ábra: A közös európai haderő megítélése \\ (A számok az adott választ megjelölö interjúalanyok számát jelölik)}

Forrás: a szerző szerkesztése

Az interjúalanyok véleménye jelentősen eltért akkor is, amikor arról kérdeztem őket, hogy szükség van-e középtávon közös európai haderő létrehozására, ha ehhez kormányzati döntési jogokat adna át Magyarország az Európai Uniónak (4. ábra). Ez azért is érdekes, mivel a 2019 során, a Honvédelmi Minisztériumban folytatott interjúk szinte kivétel nélkül szkeptikusak voltak egy ilyen közös haderő létrehozását illetően. ${ }^{17}$ Jóllehet, ez a szkepticizmus a 2020-as interjúk során is megmutatkozott, mégis a válaszadók csaknem fele érvelt amellett, hogy szükség lenne közös európai haderőre. Igaz ugyanakkor az is, hogy Orbán Viktor miniszterelnök 2020 során maga is többször említette meg, hogy szükség lenne közös európai haderőre, így e tekintetben elképzelhető, hogy a politikai diskurzus markán-

17 Etl (2020) i. m. 90-91. 
sabban beépült a szakértői percepciókba is. ${ }^{18}$ Az interjúalanyok közülük öten rögtön hozzá is tették azonban a válaszukhoz, hogy a létrejöttét egy ilyen haderőnek nem tartják reális opciónak, pontosan a nemzeti szuverenitást érintő kérdések miatt. Egy interjúalany arra mutatott rá, hogy bár az alapvető szuverenitásra vonatkozó jogoknak továbbra is nemzetállami keretben kellene maradniuk, ugyanakkor a végrehajtási kérdésekre vonatkozó területeken lehetne bizonyos kompetenciákat csoportosítani. Egy másik válaszadó pedig azt hangsúlyozta, hogy bár az európai haderő szükséges, ugyanakkor ennek kérdése jelenleg „téves irányba viszi ez a diskurzust”, és sokkal inkább „az együttmüködésre, interoperabilitásra van szükség, valamint a percepciókat kell közelíteni egymáshoz".

Azok a válaszadók, akik szerint nincs szükség ilyen közös európai haderőre legtöbbször a nemzeti szuverenitást érintő problematikával indokolták a válaszukat. Akadt olyan interjúalany is, aki arra mutatott rá, hogy a magyar álláspont nem teljesen egyértelmü ebben a kérdésben, mert bár az ország támogatná az európai védelempolitikai integrációt, ugyanakkor alapvetően szuverenitásféltő külpolitikát folytat. Több interjúalany érvelt amellett is, hogy a müveleti képességek fokozásához nem szükséges közös európai haderö, és a képességeket sokkal inkább tagállami keretben kell megerősíteni. Ehhez hasonlóan két interjúalany is azt hangsúlyozta, hogy ha a közös európai haderőnek pusztán az lenne a célja, hogy Franciaország afrikai müveleteit támogassa, akkor nincs szükség ilyen struktúrára.

\section{A Visegrádi Négyek biztonságpolitikai együttmüködése}

Ezt követően az interjúalanyokat arra kértem, hogy értékeljék a Visegrádi Négyek biztonságpolitikai együttműködését. A válaszok alapján egyértelműen pozitívumként azonosítható, hogy nem volt olyan interjúalany, aki nem kívánatosnak tartotta volna a négy ország közti biztonságpolitikai együttmüködést. A gyakorlati eredmények terén ugyanakkor már megoszlanak a vélemények.

A legtöbb válaszadó hangsúlyozta, hogy alapvetően biztató és pozitív eredményként értékelhető magának az együttmüködésnek a léte, vagy, ahogy egy interjúalany fogalmazott, „összességében jobb, hogy van, mintha nem lenne”. Ez ugyanakkor érzékelteti azt is, hogy az együttműködés biztonságpolitikai mélységét illetően jelentős szkepticizmus azonosítható a biztonságpolitikai szférán belül. A válaszadók közel kétharmada mutatott rá a csoport korlátjaira ezen a téren. Így például voltak, akik a négy ország közti eltérö fenyegetettségpercepció problematikáját hangsúlyozták, mások a négy ország erőforrásainak korlátozottságára mutattak rá, megint mások arra mutattak rá, hogy a csoport tevékenysége inkább normatív és politikai szinten fontos, nem pedig a konkrét gyakorlati, biztonságpolitikai eredmények szintjén. Két válaszadó szerint ezen kicsit lendített a migráció kérdése, amelynek mentén, a határvédelem területén fokozódott az együttmüködés, ugyanakkor egy másik interjúalany úgy nyilatkozott, hogy inkább V2 + 2-ről beszélhetünk jelenleg, annak köszönhetően, hogy Szlovákia és Csehország más külpolitikai utat követ, mint Lengyelország és Magyarország.

18 Lásd például: Orbán Viktor sajtónyilatkozata a Bledi Stratégiai Fórum után. [online], 2020. 08. 31. Forrás: miniszterelnok.hu [2020. 11. 16.] 
A gyakorlati eredményeknél maradva több válaszadó is kiemelte a V4 harccsoport létrejöttét, ugyanakkor egy válaszadó ennek kapcsán amellett érvelt, hogy bár ez a harccsoport a V4-ek egyetlen gyakorlati eredménye a biztonságpolitika terén, ez mégsem annyira elönyös a csoport szempontjából a harccsoport-koncepció alkalmazhatatlansága miatt. Ezen túl pedig több válaszadó is rámutatott arra, hogy nem látja, hogy a V4-ek összehangolták volna beszerzési döntéseiket a saját haderőik modernizációja során, ami megint inkább a csoport korlátjaira mutat rá - és egyúttal azt is érzékelteti, hogy miért a V4-eket jelölte meg sok interjúalany azon szövetségesek között, akikkel érdemesebb volna Magyarországnak mélyebb katonai együttmüködést kialakítani.

Összességében tehát a V4-ek létezésének percepciója inkább pozitív, azonban a biztonságpolitikai együttműködés gyakorlati aspektusait tekintve meglehetősen szkeptikusak a szakemberek. Ez egybecseng a Honvédelmi Minisztériumban folytatott interjúkkal is, amelyek során az interjúalanyok következetesen hangsúlyozták a V4 fontosságát a biztonság- és védelempolitika terén, ám csak néhányan tudták az együttmüködést mélyebben értékelni, annak gyakorlati korlátjai miatt. ${ }^{19}$

\section{A védelmi kiadások alakulása és a Magyar Honvédség jövője}

Ezt követően az interjúalanyoknak arra kellett válaszolniuk, hogy hogyan vélekednek a Magyar Honvédség finanszírozásáról a következő öt évben. Ennek kapcsán egyértelmü konszenzus azonosítható a válaszadók között, hiszen egyik interjúalany sem tekintett negatívan az elmúlt évek során végbement növekedésre a védelmi kiadások terén. Sőt, ezzel ellentétben, az interjúalanyok szinte mindegyike szükségesnek és biztatónak találta a védelmi költségvetés növelését - tekintettel arra, hogy az ezt megelőző időszakban a Magyar Honvédség tartósan alulfinanszírozottá vált, és több évtizedes lemaradást kell pótolnia. Több válaszadó utalt arra is, hogy ez a trend hozzájárul Magyarország hitelességének növekedéséhez is a szövetségen belül, azáltal, hogy képessé teszi az országot a NATO-n belüli vállalásainak teljesítésére. Mindez azt is jelenti, hogy a magyar biztonság- és védelempolitikai szférán belül meglehetősen stabil egyetértés mutatkozik abban, hogy Magyarországnak a korábbiaknál többet kell költenie saját védelmére. Fontos, és a konszenzust tovább erősítő tényező, hogy ez összességében szoros egyezést mutat a 2019 őszén, a Honvédelmi Minisztériumban elvégzett interjúk eredményeivel. ${ }^{20}$

A jövőbeli védelmi kiadásnöveléssel kapcsolatban azonban már más a helyzet, hiszen az interjúalanyok csaknem fele mutatott rá kisebb-nagyobb bizonytalansági tényezőkre ezzel kapcsolatban. E válaszokból összességében az is kirajzolódik, hogy a védelmi kiadásokkal kapcsolatos bizonytalanság több, egymástól elkülöníthető okra vezethető vissza.

9 Etl (2020) i. m. 91-92.

20 Etl (2020) i. m. 92. 
A válaszadók egy része arra mutatott rá, hogy a koronavírus-járvány gazdasági hatásai hosszú távon elérhetik a védelmi szférát, ezáltal pedig véget vethetnek a pozitív trendnek. Más válaszadók ugyanakkor azt is kiemelték, hogy látszólag a védelmi kiadások jelen pillanatban magasan állnak a kormányzati prioritáslistán, így nem feltétlenül ezek válnának elsőként az esetleges megszorítások áldozatává. Két interjúalany arra mutatott rá, hogy védelmi kiadások növelésével kapcsolatban nincs többpárti konszenzus, és egy esetleges kormányváltás szintén veszélyeztetheti a hosszú távú növekedést. További két interjúalany mutatott rá arra, hogy nem egyértelmü milyen hatékonysággal tudja felhasználni a Magyar Honvédség a megnövekedett forrásokat, egy válaszadó pedig a NATO-ban elfogadott GDP 2\%-os ráfordítási arányszám hasznosságát kérdőjelezte meg, rámutatva annak megalapozatlan jellegére.

Összesen öt válaszadó emelte ki a beszerzések mentén bejelentett offsetek (ellentételezések) jelentőségét, és azt, hogy ezek a védelmi szektoron túlmutató, gazdasági hasznot is hozhatnak. ${ }^{21}$ Egy válaszadó pedig kifejezetten amellett érvelt, hogy a védelmi kiadásokat nem csak önmagukban kell vizsgálni, hiszen Magyarország „a biztonsági helyzetre adott reakcióit nem kizárólag csak védelempolitikai érdekek mentén határozza meg, hanem öszszekapcsolva azt egyéb, gazdasági-politikai érdekekkel”.

Végül az interjúalanyoknak arra a kérdésre kellett válaszolniuk, hogy szerintük elsősorban mely területekre kellene fókuszálni a Magyar Honvédség fejlesztése során (5. ábra). E kérdéssel kapcsolatban a válaszadók több mint fele utalt valamilyen módon arra, hogy a személyi állománnyal kapcsolatos kérdések megoldása lenne az egyik legfontosabb feladat a szervezet számára. Az, hogy a humán eröforrással kapcsolatos kérdések a Honvédelmi Minisztériumban elvégzett interjúk során is kiemelt helyet foglaltak el, jól érzékelteti azt is, hogy e kérdés meghatározó fontosságú lehet középtávon is a magyar biztonság- és védelempolitikai szféra dolgozói szerint. ${ }^{22}$

E problémakör ugyanakkor több, különbözö kérdést foglal magában. Az egyik legfontosabb, több válaszadó által is hangoztatott kihívás a bérfejlesztés kérdésének megoldása és a katonák életkörülményeinek javítása. Emellett többen kiemelték azt is, hogy a humán erőforrás fejlesztéséhez elengedhetetlenül fontos lenne a képzési körülmények javítása és modernizálása is. Végül pedig - szintén a humán erőforrás kérdéséhez kapcsolódva - több interjúalany rámutatott a társadalom és a védelmi szféra közti kommunikáció javításának fontosságára, annak érdekében, hogy egyfelől legyen egy társadalmi tudatosság a védelmi kérdésekben, másfelől pedig azért, hogy a társadalomban legyenek honvédelemre elszánt, kiképzett emberek (például az önkéntes tartalékos rendszeren keresztül).

\footnotetext{
${ }^{21}$ Az elmúlt évek során bejelentett beszerzések nyomán ilyen ellentételezésnek tekinthető például a lőfegyverek gyártása Kiskunfélegyházán vagy éppen a gyulai repülőgépalkatrész-gyártó vegyesvállalat létrehozása.

22 Etl (2020) i. m. 92.
} 


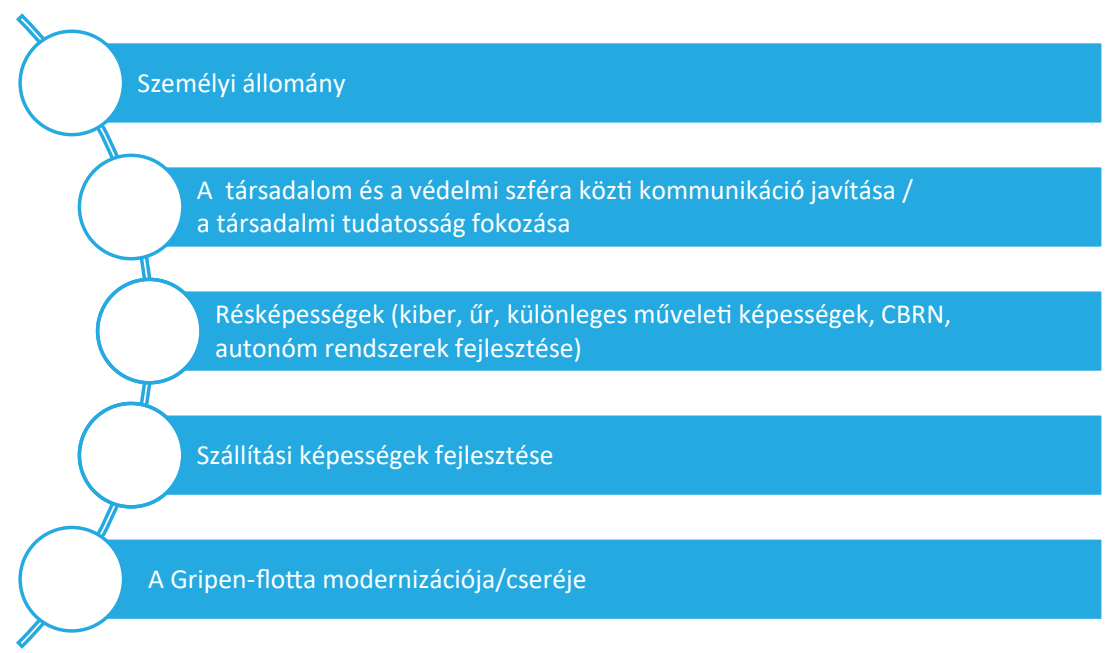

5. ábra: Az interjúalanyok által azonosított területek a Magyar Honvédség modernizációja szempontjából Forrás: a szerző szerkesztése

A személyi állományon túlmutatóan a válaszadók körülbelül fele utalt arra is, hogy a Zrínyi 2026 keretében már bejelentett eszközbeszerzések mellett érdemes lenne a Magyar Honvédség fejlesztése során bizonyos puhább, részképességek fejlesztésére is koncentrálni az erőforrásokat, amelyek összességében hozzájárulhatnának Magyarország nemzetközi presztízsnövekedéséhez és a szövetségen belüli megbecsültségéhez is. A különböző válaszok során ilyen részképességként említett területek között szerepelt a kibervédelem, az ürvédelem, a különleges műveleti képesség, a CBRN-képesség és a most kiépülő hadiipar berkein belül az autonóm rendszerek fejlesztésének képessége. Ez szintén bizonyos hasonlóságot mutat a Honvédelmi Minisztériumban elvégzett interjúk eredményeivel, amelyek során több válaszadó szintén az új típusú kihívások kezelésére alkalmas képességek fejlesztését említették jelentős feladatként. Végül pedig, a 2020. szeptemberi interjúk során, a konkrét eszközbeszerzésekre utalva három válaszadó említette, hogy fejleszteni kell a Honvédség szállítóképességeit, míg két válaszadó a Gripen-flotta javítását/cseréjét tartja szükségesnek az évtized során.

\section{Következtetések}

E kutatási projekt alapvető célja az volt, hogy még képet kaphassunk az egyébként rendkívül zárt, magyar biztonság- és védelempolitikai szféra biztonságpercepciójáról, és ezáltal jobban megérthessük a magyar biztonság- és védelempolitikai folyamatokat.

Az interjúk alapján kirajzolódó biztonságpercepció arra mutat rá, hogy meglehetősen stabil konszenzus van a szakemberek között arra vonatkozóan, hogy az ország biztonságés védelempolitikai helyzete alapvetően stabil, ugyanakkor a biztonságpolitikai környezet sok aspektusból tekintve romló tendenciákat mutat. Szintén stabil konszenzus azonosítha- 
tó Magyarország szövetségesi rendszerével és legfontosabb szövetségeseivel kapcsolatban is, amelyek között rendszerint az Egyesült Államok, Németország és a V4-ek kerültek említésre. Bár a percepciók alapján az ország biztonság- és védelempolitikai helyzete stabil, több válaszadó is említett bizonyos fenyegetéseket az interjúk során. A nem állami fenyegetéseket tekintve leginkább a globális hatalmi verseny élénkülése, valamint a demográfiai kihívások, a kiberfenyegetések jelentette kihívások és a nemzetközi terrorizmus, valamint a migráció kerültek elötérbe ennek kapcsán - igaz ugyanakkor, hogy utóbbihoz ambivalens percepciók is kapcsolódnak. Ehhez hasonlóan, bár egyetértés mutatkozik a tekintetben, hogy jelenleg egyik állam sem jelent közvetlen fenyegetést Magyarország számára, több interjúalany is kiemelt bizonyos országokat, amelyekhez különböző biztonságpolitikai kihívások kapcsolódhatnak. Ennek kapcsán leginkább Oroszország, Ukrajna és Kína került előtérbe. Látványosan széttartó percepciók azonosíthatók ugyanakkor az európai védelmi együttmüködések jövőjével kapcsolatban. Egyfelöl elmondható ugyan, hogy a megkérdezettek egyetértettek abban, hogy szükséges az európai védelmi képességek megerősítése, ennek megvalósításával kapcsolatban ugyanakkor már megoszlanak a vélemények. Mindez arra világíthat rá, hogy a szakmai közösség megosztott az európai védelmi együttmüködések stratégiai irányát illetően, e probléma orvoslása pedig kulcsfontosságú lehet Magyarország biztonság- és védelempolitikájának jövője szempontjából. A kutatás ezen túlmenően arra is rávilágított, hogy a biztonság- és védelempolitikai szféra jelentős része fontosnak tartaná a visegrádi együttmüködés biztonságpolitikai aspektusainak elmélyítését, ugyanakkor rendkívül korlátozottnak tartja az eddig elért eredményeket e tekintetben. Végül, az eredmények alapján az is látható, hogy a megkérdezett szakértők között percepcionális konszenzus van a védelmi kiadások növelésének szükségessége kapcsán, és a legtöbben a humán erőforráshoz kapcsolódó problémákat látják a legnagyobb kihívásnak a Magyar Honvédség jövője szempontjából.

\section{FELHASZNÁLT IRODALOM}

Csiki Varga Tamás - Tálas Péter: Magyarország új nemzeti biztonsági stratégiájáról. SVKI Elemzések, (2020), 17. Etl Alex: A magyar biztonságpercepció elemzése. Nemzet és Biztonság, 13. (2020), 2. 80-93. DOI: https://doi. org/10.32576/nb.2020.2.6

Etl Alex - Tálas Péter: A magyar biztonságpercepció átalakulása 1999-2019 között. Nemzet és Biztonság, 13. (2020), 2. 94-112. DOI: https://doi.org/10.32576/nb.2020.2.7

Orbán Viktor sajtónyilatkozata a Bledi Stratégiai Fórum után. [online], 2020. 08. 31. Forrás: miniszterelnok.hu [2020. 11. 16.]

Radványi Lajos: A magyar lakosság biztonságfelfogása és értékpreferenciái, 1999-2008. Nemzet és Biztonság, 2. (2009), 2.9-22.

\section{Jogi forrás}

1163/2020. (IV. 21.) Korm. határozat Magyarország Nemzeti Biztonsági Stratégiájáról 